\title{
Designing mobile learning: Empirical journey to reality in Malaysian secondary school context
}

\author{
Rashidah Rahamat \\ English Language Teaching Centre, Ministry of Education, \\ Malaysia
}

Email: rashidah.rahamat@gmail.com

\begin{abstract}
Designing a conducive and meaningful learning environment in the teaching and learning is thought-provoking tasks. The use of teaching materials will be one of the resources and normally teachers or the practitioners will need to put a lot of considerations will assist teachers in creating the desired learning outcomes. This paper aims to share the initial steps engaged in the process of creating a mobile learning concept which is applicable for Malaysian Secondary School Education. Therefore, the mixture of qualitative and quantitative measure was deployed in order to achieve the primary objective of creating a workable mobile learning concept. The findings from analysing 40 documents had unlocked a few gaps to be filled in: they enabled the focus to be on the small "l" component for the English Language secondary school syllabus as well as on the feasible methodology to be applied for the real mobile language learning context. Whereas the input from the need analysis provided more insights on how the content for the dry literature components could be arranged in the learning context. Hence, by combining the input from the documents analysis and need analysis data, they had proven to be empirically and beneficially useful steps to be taken before embarking on the actual conception of any teaching and learning design to be proposed or implemented. These initial steps had proven to be beneficial for the next stage of designing the mobile learning environment in Malaysian secondary school context.
\end{abstract}

Keywords: material design, mobile learning, ICT, secondary school, education.
Received:
Revised:
Accepted:
Published:
14 November 201810 February 2019
28 February 2019
28 February 2019

\section{INTRODUCTION}

Education is no longer bound to be only within the four walls of the classroom and thus, those involved in the education sector should consider making the learning process be more mobile and flexible using mobile learning concept available. Malaysia is now in the process of moving towards realizing the second wave of the educational transformation through the Malaysian Educational Blueprint (MEB) known as Pelan Pembangunan Pendidikan Malaysia (PPPM) 2013-2025. Through the 11 transformation items aimed to be achieved by 2025, the use of technology would be one of the items which 
has been given focus. Despite of the efforts to ensure that technologies are very well utilized and realized in the classroom, there are some educators who are still sceptical of making full use of the available technologies to assist the learning process. The culture of using technology for learning is now on the move. Buzzing sound for e-learning which has created a long dejected "eeeeee!" among teachers or educators when it was first introduced and this "e" vowel would gradually change to the long questionable "mmmmmm!?" when the terminology for mobile learning or m-learning came into picture. No matter how those letters (vowel e and consonant $\mathrm{m}$ ) were pronounced, dejectedly or questionably, teachers or those in education world need to know that, they must accept the fact, the trend for ICT in education is now has evolved tremendously. Learning is no longer confined to the four walls of the classroom. Flexibility to learn anywhere anytime should be taken into consideration in preparing students on what to learn.

The development of generations from Babyboomers, Millennials, Netgenerations, Z-Generations and Alpha Generations is another point of discussions showing the use of technologies in teaching and learning. Educators especially teachers are no longer expected to teach the way we used to be taught: the chalk and talk. Motlik (2008) has mentioned that the concept of mobile learning, especially with the use of mobile phone in some of the developed countries in Asia. The use of mobile technologies, which is now being considered as the affordable to be owned by school students, have suitable designs and opening more opportunities for flexible learning. Motlik also highlighted that, a few researches carried out such as in Philipines, Thailand and Japan, have shown positive results. Therefore, the foreign studies have proved that, the use of mobile technologies can be explored further for education purposes. The initiative to explore on the trend of using mobile technologies in teaching and learning English as the second language was merely based on how foreign scholars conducted theirs. Therefore, this paper aims to share the steps taken in order to realize the concept of mobile learning which is applicable and proven to be practical in Malaysian education context.

\section{ICT in education}

ICT or the Information and Communication Technology in education is usually associated with the use of the latest technologies related to the use of computer. However, this term includes the other type of technologies such as radio and television. According to Tinio (2002, p.3), any technologies related to ICT has been announced "...as potentially powerful enabling tools for educational change and reform...”. The process of teaching and learning would not only turn to be engaging and active, however, would also help to expand the access to education and strengthen the relevance of education. However, these aims could be realized if only the ICT technologies are used appropriately and wisely. Therefore, the vital aspect of effective use of ICT in education is not the latest technology, but the need to understand how and whether it can enhance people's learning (Education in ICT, 2006).

According to Chapelle (2003), the technology-based learning activities would offer more advantages and opportunities for natural learning, besides being effective, fast and giving more impact on the students' achievement 
compared to the conventional way. The activities using technologies are more flexible and could be developed further. However, Legutke (2005) stresses that the aspects related to the use of technology in education should concern more on how to apply the use of latest technology into the process of teaching and learning. To these researchers, the most important aspect is to integrate the technology into the curriculum with responsibility, meaningfulness and efficiency.

\section{Mobile learning}

Mobile learning and mobile technologies are words which trigger some confusion regarding the specific definitions. The phrase mobile learning or $\mathrm{m}$ Learning is commonly associated with the use of mobile technology especially the mobile phones (Cavus, Bicen \& Akçil, 2008; Naismith et al, 2004). Naismith et al (2004) state that the term mobile is generally referring to something which is portable and personal; some scholars classify the portable technologies such as hand phones, handheld computers or any devices which can be put into one's pocket as the most suitable combination for m-Learning definitions. Alexander (2004) views m-Learning as a wireless learning, universal and it is a subset of e-Learning which would focus more on using the personal computers such as desktop computers with internet access to learn, whereas m-Learning would be more on the access to internet via the portable device such as the mobile phones or game consoles. Therefore, the integration of mobile learning among school students is seen as alternative which can help to increase their interest and motivation.

\section{Mobile technologies}

Mobile technologies would usually be associated with the devices which would be used and portable. Sharples (2000) states that technologies can be used in learning as: 1) an intelligent tutor system, 2) simulators and learning tools as well as pedagogy agent, 3) system device and resources, 4) communication device, and 5) simulation classrooms. In addition to that, Naismith et al (2004) give two dimensions of mobile technologies which are: 1) personal and shared, and 2) portable and static. These researchers also point out that there are six learning theories related to the use of mobile technologies such as behaviorism, constructivism, situated, collaboration, informal learning and lifelong learning, and support in teaching and learning. Today's generation is keener to conduct information exploring using technology and their world is dominated by this high- tech device. Thus, this enables them to engage in any networking globally (Mohd Arif \& Rosnaini, 2003; Roziah, 2004).

The Information and Communication Technology is seen to have the ability as a medium for students to access to knowledge. This is aslo where the term e-learning started to be used; students are using the electronic technology particularly computers to access to the internet in order to get information. Now, the e-learning has been evolutioned towards the use of mobile technology to acess and improve the quality of education (Pieri \& Diamantini, 2009). In today's era, the internet would not only be accessed from the desktop computers, but it can also be accessed from any mobile technologies such as mobile phones or laptops. 


\section{Mobile technologies and the net generation}

The third Generation or better known as $3 \mathrm{G}$ is said to have started around $2003 / 2004$. Andersson et al (2006) report that in 2005 it was estimated that about 2 billion people world wide were using hand phones and for about 680 million mobile phones were sold. Economides dan Grousopoulou (2008) mention that one out of six people in the world owned a mobile phone, Personal Digital Assistant (PDA) and laptop with Wireless Fidelity (Wi-Fi). This is supported by the findings by ITU (2006) which found that hand phone users were double than PC users and recent report by ITU (2018), "Among the various types of ICT equipment used today, smartphones and other mobile devices have become pervasive and desirable items amongst the world population..". Most of the teenagers treat hand phones as a fashion for their social actvities regardless of location (Economides \& Grousopoulou, 2008). These groups of teenagers aged 13 to 17 years old can be grouped as the millennial sudents who were born in the 1990's that was when the technology was booming and coming into our daily lives (Rocca, 2009). Apart from that, McAlister (2009) agrees that these millennial students are comfortable and confident when they are dealing with computers and even would be delighted with the "multi-sensory engagement" related to variety of media used in their learning. This researcher further explains "...using these new tools in combination with our sound pedagogical knowledge will lead to well-grounded, engaged students who will continue to explore the world...beyond their lesson years..." (McAlister, 2009, p.13-15).

\section{Koole's mobile learning framework}

Koole's Mobile Learning Theory (2009) is also known as FRAME Model or Framework for the Rational Analysis of Mobile Education. This framework has highlighted three main aspects in mobile learning which are: the learners, devices and social. The concept which is proposed in seen through the connection between the technology, human learning capacity and social interaction (Koole, 2009). The device as mentioned in this framework, would be more focused on the physical criteria, the ability to receive input and produce output, the ability to save and extract files, speed as well as the limitations of the technology. As for the learners' factor, the considerations are basically referring to the learners' cognitive ability, memory, previous knowledge, emotion and motivation. In addition to those two aspects, the social factor in this framework is focusing more on two things, which are: 1) the communication and cooperation, and 2) the social interaction. Most importantly, the focal point of Koole's Framework in mobile learning is the integration of the three aspects: device, learners and social. Thus, preparation of mobile learning content or concept should take into considerations the applications of strategies as well as techniques which will assist to enhance the presentation of the information to learners be more efficient. The following illustration shows the simplified version of what Koole has in the framework. 


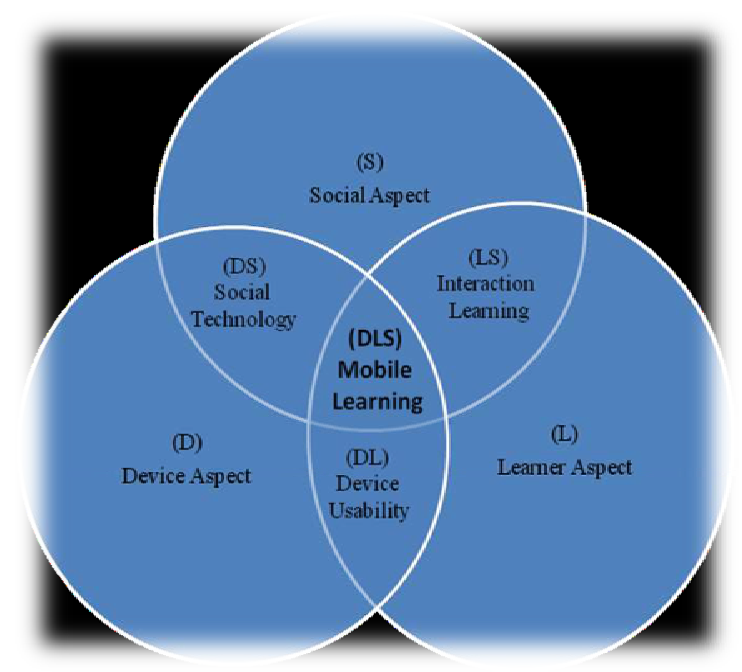

Figure 1. Koole's Mobile Learning Framework

\section{Motiwalla's Mobile Learning Model}

Motiwalla's Mobile Learning Model (2007) illustrates the integration of the mobile connectivity and the e-learning application as the prerequisite conditions towards mobile learning. The delivery of the content will be more effective with the combination of the Push and Pull mechanism. Motiwalla (2007) highlights that, content delivery will be more useful if it is personalised and collaborated with the concept of Push and Pull. The concept of Push and Pull is when the content is pushed to the students by the "pedagogical agents and mentors" via the system tools and resources. The target audience (the students) have the power to control and filter the learning content whether to pull out the learning content which is done when they responded to the information received. The learning content can be pushed via Short Messages Service (SMS), Instant Messenger, alerts such as calendar, website, discussion rooms or boards; the students can pull the learning content through the websites, discussion rooms or boards or chat forum. The integration of the elearning materials be pushed or pulled thru the mobile technology applications would be the concept of Motiwalla's mobile learning concept.

\begin{tabular}{|c|c|c|c|}
\hline \multicolumn{2}{|r|}{$\begin{array}{l}\text { Personalized } \\
\text { Content }\end{array}$} & $\begin{array}{c}\text { Collaborative } \\
\text { Content }\end{array}$ & \\
\hline $\begin{array}{r}\text { PUSH } \\
\text { Mechanism }\end{array}$ & $\begin{array}{l}\text { Pedagogical Agents } \\
\& \text { Mentors }\end{array}$ & Communication Aids & $\begin{array}{l}\text { SMS, IM, Alerts, } \\
\text { Scheduling Calendars }\end{array}$ \\
\hline \multirow[t]{3}{*}{$\begin{array}{r}\text { PULL } \\
\text { Mechanism }\end{array}$} & $\begin{array}{l}\text { System Tools \& } \\
\text { Resources }\end{array}$ & Simulated Classrooms & $\begin{array}{l}\text { WMLm websites, } \\
\text { Discussion Boards \& Chat } \\
\text { Forums }\end{array}$ \\
\hline & $\begin{array}{l}\text { Alerts, Scheduling } \\
\text { Calendars, WML, }\end{array}$ & $\begin{array}{l}\text { SMS, IM, Discussion } \\
\text { Boards \& Chat Forums }\end{array}$ & \\
\hline & Wensies & & $\begin{array}{l}\text { ?arning } \\
\text { lications }\end{array}$ \\
\hline
\end{tabular}

Figure 2. Motiwalla (2007) Mobile Learning Framework 


\section{METHOD}

The method of this study deployed the mixture of qualitative and quantitative approach. The qualitative approach was used based on the document analysis done on 40 articles compiled and the quantitative approach was based on the need analysis conducted with 235 secondary school students.

\section{Document analysis}

A review on a few studies conducted was done to find the details of how studies were conducted. A total of 40 related articles were compiled and reviewed. Table 1 displays the summary of the studies. A critical analysis was done on the articles which aimed to look at the gap for the research to be conducted. The articles were selected basically by narrowing down on mobile learning researches conducted based on the year of the publication, the focus of the studies (the countries, samples, topic of the studies), the methodology, the devices, the application as well as the concepts used. The following table summarizes the selection of the articles to be reviewed.

Table 1. The Summary of the Reviewed Articles

\begin{tabular}{|c|c|}
\hline Aspect & Details \\
\hline Year of publication & $2005-2011$ \\
\hline Focus & Mobile learning researches \\
\hline Countries & Foreign and Malaysia \\
\hline Samples & $\begin{array}{l}\text { Higher Institution, Secondary } \\
\text { Professional and General }\end{array}$ \\
\hline Subject selected for the studies & English \& Other subjects \\
\hline Focus & $\begin{array}{l}4 \text { skills (Reading, Writing, Listening, Speaking), } \\
\text { Grammar, Vocabulary, Literature }\end{array}$ \\
\hline Method & Survey, Experimental or Mix Method \\
\hline Instruments & $\begin{array}{lll}\text { Questionnaire, } & \text { Interview, } & \text { Document } \\
\text { Observation, Test } & \end{array}$ \\
\hline Concept & Mobile or Blended (Face to face and Mobile) \\
\hline
\end{tabular}

\section{Needs analysis questionnaire}

To support the gap from the document analysis, a need analysis questionnaire was prepared. The content of the questionnaire was basically adaptation from previous studies. The questionnaire was distributed to six randomly selected secondary schools in one of the states in the country. The following table is the distributions of aspects in the questionnaire. 
Table 2. The Sections in the Questionnaire for Needs Analysis Survey

\begin{tabular}{clc}
\hline Section & \multicolumn{1}{c}{ Aspect } & No. of Item \\
\hline A & $\begin{array}{l}\text { Demographic information } \\
\text { Mobile Technology Information }\end{array}$ & 14 \\
\hline & $\begin{array}{l}\text { Perceptions towards learning } \\
\text { literature in English. } \\
\text { Perceptions towards problems in } \\
\text { learning literature in English } \\
\text { Perceptions towards literature } \\
\text { genre in English }\end{array}$ & 13 \\
\hline C & $\begin{array}{l}\text { Perceptions towards the use of } \\
\text { mobile handphone for future } \\
\text { learning. }\end{array}$ & 16 \\
\hline D & $\begin{array}{l}\text { The content for the mobile } \\
\text { learning package for literature in } \\
\text { English }\end{array}$ & 29 \\
\hline
\end{tabular}

\section{RESULTS AND DISCUSSION}

The results of the analysis will be presented based on the examination carried out on the 40 mobile learning articles and the needs analysis survey.

\section{The critical analysis of mobile learning researches}

The findings of the 40 documents revealed attention-grabbing results especially in searching for the gaps for the intended research. The studies conducted on mobile learning managed to reveal not only noteworthy results but also eye-opener to the methodologies applied. The results of the 2005 till 2011 articles showed that, only 3 studies were conducted in Malaysia as compared to 37 studies conducted in other countries. Apart from that, most of the samples used in the 40 studies were higher institution students in 22 studies, 5 studies used secondary and primary school students respectively, another 4 studies used samples from the professionals and from general sectors. Besides that, a total of 26 studies used other subjects to in their research as compared to English subject with only 14 studies and only one study focused on literature. Further analysis showed that, majority of the researchers conducted survey (22 studies) in comparison to experimental and mix method. As for the instruments used, questionnaire seemed to be the common one exercised by the researchers. In addition to that, the calculation towards the concept of the studies disclosed a total of 22 studies did a full mobile learning studies rather than the blended mode. Table 3 displays the summary of the mentioned findings. 
Rahamat, EduLite: Journal of English Education, Literature, and Culture Vol.4, No.1, February 2019, 13-24

Table 3. Summary of the document analysis

\begin{tabular}{|c|c|c|}
\hline Aspect & Details & Data gathered \\
\hline Countries & Foreign and Malaysia & $\begin{array}{l}\text { Foreign: } 37 \\
\text { Malaysia: } 3\end{array}$ \\
\hline Samples & $\begin{array}{l}\text { Higher Institution (HI), Secondary } \\
\text { School (SS), Primary (PS), } \\
\text { Professional (P) and General (G) }\end{array}$ & $\begin{array}{l}\text { HI: } 22 \\
\text { SS: } 5 \\
\text { PS: } 5 \\
\text { P: } 4 \\
\text { G: } 4\end{array}$ \\
\hline $\begin{array}{l}\text { Subject selected } \\
\text { for the studies }\end{array}$ & English \& Other subjects & $\begin{array}{l}\text { English: } 14 \\
\text { Other subjects:26 }\end{array}$ \\
\hline Focus & $\begin{array}{l}4 \text { skills (Reading, Writing, Listening, } \\
\text { Speaking), Grammar, Vocabulary, } \\
\text { Literature }\end{array}$ & $\begin{array}{l}4 \text { skills: } 28 \\
\text { Grammar: } 6 \\
\text { Vocabulary: } 10 \\
\text { Literature: } 1 \\
\end{array}$ \\
\hline Method & $\begin{array}{l}\text { Survey, Experimental or } \\
\text { Method }\end{array}$ & $\begin{array}{l}\text { S: } 22 \\
\text { E: } 8 \\
\text { MM: } 4\end{array}$ \\
\hline Instruments & $\begin{array}{l}\text { Questionnaire, Interview, Document } \\
\text { Analysis Observation, Test }\end{array}$ & $\begin{array}{l}\text { Q: } 29 \\
\text { I: } 17 \\
\text { DA \& OB: } 6 \\
\text { T:8 }\end{array}$ \\
\hline Concept & $\begin{array}{l}\text { Mobile or Blended (Face to face and } \\
\text { Mobile) }\end{array}$ & $\begin{array}{l}\text { M: } 27 \\
\text { B: } 13\end{array}$ \\
\hline
\end{tabular}

\section{The needs analysis survey}

The needs analysis survey carried out with 235 randomly selected secondary school students also highlighted fascinating results especially in terms of their perceptions in using handphones for future learning. Majority of the mixed ability students who responded to the items related with their views towards the usage of their mobile devices for learning. The examinations towards the mobile handphones owned by the students showed 215 of them owned handphones as compared to only 20 who did not have one. These 215 students comprised $91 \%$ of the samples involved in the survey. This data is as displayed in Figure 3.

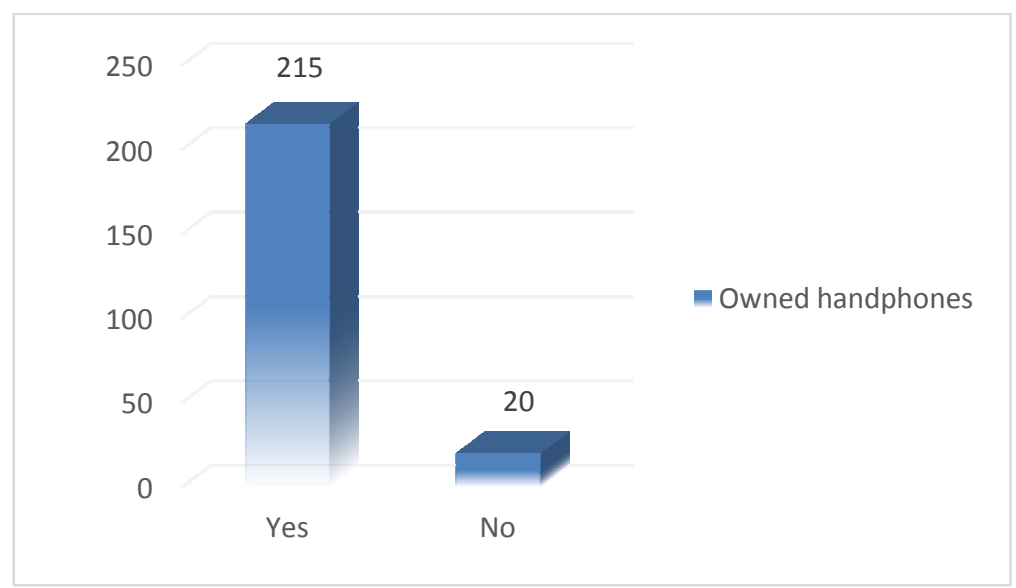

Figure 3. The handphones owned by the students 
EduLite Journal of English Education, Literature, and Culture

In addition, the results of their readiness towards mobile learning also revealed attention-grabbing point. Apart from that, the descriptive results also indicated that the students were ready in term of their willingness to pay for the Internet access where, a total of 131 (56\%) students willing to pay less than RM30, 70 (30\%) of them willing to pay RM30-RM60, 22 (9\%) students willing to pay between RM61-RM90 and the balance of 12 (5\%) of the secondary students were willing to pay RM91-RM120. Another section in the survey asked the respondents to put their choice to use their mobile devices as learning tools. The responses were encouraging; 175 (75\%) of the students wanted to use their laptop, $33(14 \%)$ of the students chose their smartphones and the remaining $27(11 \%)$ of them selected their handphones as the learning tools. In addition to that, the respondents were also asked to give their response to the question or statement asking about their willingness to learn anytime and anywhere. The outcomes of the responses revealed that these 235 students were positive towards that learning context: anytime, anywhere learning. High frequency towards the choice "Yes" which was 170 out of 235, "Maybe" with only 51 students and the balance of 14 pointed at "No". Hence, $70 \%$ of these teenagers wanted to learn anytime and anywhere as compared to those who decided to select "No" to that context of learning. Figures 4 and 5 depict these two analyses.

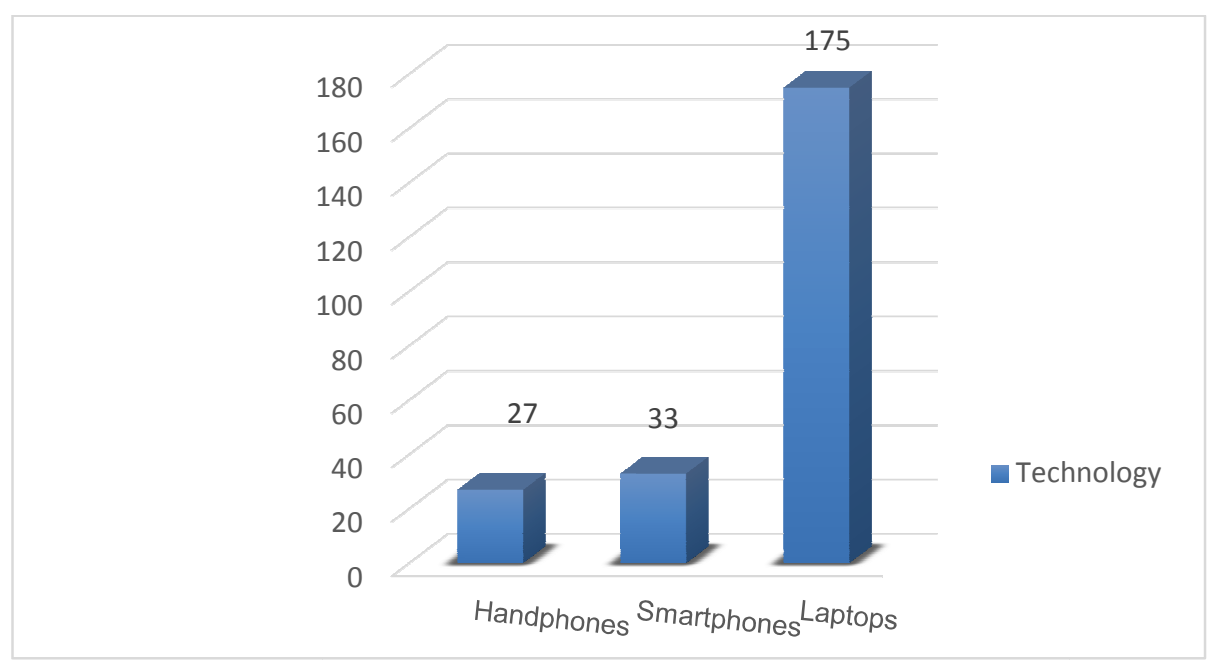

Figure 4. Willingness to Use Mobile Technology as Learning Tools. 


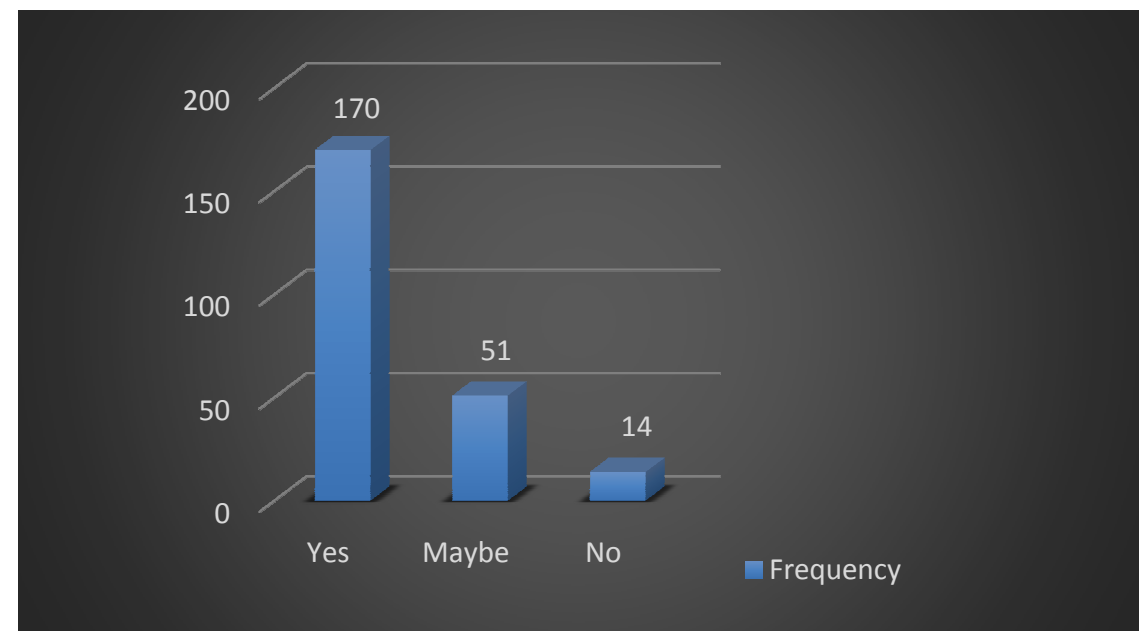

Figure 5. Willingness to learn anytime and anywhere

\section{Discussions}

The decision-making process on the mobile learning concept to be applied for the Malaysian secondary school context were made based upon these findings: the past studies conducted and the needs analysis. These two empirical findings gave insights which helped the research to be relevant and brought out meaningful outcomes. Based on the input gathered from these two sources, the choice of devices, platform, learning context as well as the processes to be conducted prior to the actual implementation of the research.

The needs analysis conducted in this research was not only useful for the context of the students' readiness but also helped the researcher on the tasks or activities to be used. Since language was the focus of the study, the four basic skills which were Listening, Speaking, Reading and Writing were the target. However, the critical analysis carried out showed the small "1" which was Literature component was the glaring gap to be filled in. The information gathered from the devices owned by the respondents was useful in a way that it provided the context which was practical for the mobile learning concept to applied for secondary school context. The methodology accumulated from the 40 studies conducted assisted this research to be planned meticulously as to abide to the policy of bringing your mobile devices to schools. Handphones are the prohibited in the school compound especially by the students. Combination of both needs analysis and critical analysis has proven to be valuable: utilising the use of technology owned by the students for the use of the out-of-classroom language learning process.

The critical analysis of the reviewed articles and the data from the need analysis were the first layers of creating the content and design of the mobile learning package. The theory of "Push and Pull" as proposed by Motiwalla (2007) was used as another layer of the foundation in the design of the whole mobile learning concept to be applied in the Malaysian school context. The content to be pushed to the package would concentrate on transforming the 
pedagogical approach for the Literature Component from the "dry and mundane" subject to something that was interesting and appealing. Therefore, the users or learners would notice the selected content that they have pulled out from the learning package was fun to explore. Therefore, fun learning concept was another major consideration taken during the design of the content. The aspects of learning Literature via technology was precisely planned, designed and tested based on the user needs as to ensure the content and context were appropriate and applicable. A few series of validation for the content for the mobile learning package were conducted as the extension from these two collections of findings. Therefore, the usefulness of the data gathered from the need analysis and past studies analysis "...are linked to a discrete set of communicative situations" (Tudor 1996:70).

\section{REFERENCES}

Alexander, B. (2004). Going nomadic: mobile learning for higher education. EDUCAUSE Review, Vol. 39 (5). Retrieved 07 November 2018.

Andersson, C., Freeman, D., James, I., Johnston, A \& Ljung, S. (2006). Mobile media and applications- from concept to cash successful service creation and launch. England: John Wiley \& Sons Ltd.

Cavus, N., Bicen, H. \& Akçil, U. (2008). The opinions of information technology students on using mobile learning. Paper Presentation on 08 International Conferences on Educational Sciences, Eastern Mediterranean University, 23-25 June, Magosa, North Cyprus.

Chapelle, C.A. 2003. English language learning and technology. Amsterdam: John Benjamins Publishing Company.

Ecnomides, A.A., \& Grousopoulou, A. 2009. Students' thought about the importance and costs of their mobile devices' features and services. Telematics and Informatics, 26: 57-84

ITU. (2018). Framework for solution to combat counterfeit ICT Devices. Retrieved on 07 November 2018 from https://www.itu.int/ITU$\mathrm{T} /$ workprog/wp_item.aspx?isn $=13825$

ITU. (2006). ITU World telecom 2006 report. Retrieved on 07 November 2018 from:

https://www.emeraldinsight.com/doi/abs/10.1108/14636690710762156

Koole, M.L. (2009). A model for framing mobile learning. In Ally, M (Eds). Mobile learning: transforming the delivery of education and training, pp.25-44. Canada: AU Press.

Legutke, M. (2005). Redesigning the foreign language classroom: a critical perspective on information technology and educational change. In Chris Davison (Eds). Hong Kong: Hong Kong University Press.

McAlister, A. (2009). Teaching the millennial generation. American Music Teacher, pp.13-15. Retrieved 19 January, 2010 from Proquest Education Journal.

Mohd Arif Hj Ismail \& Rosnaini Mahmud. (2003). Teknologi maklumat dan komunikasi di sekolah: isu dan cabaran. Dlm Hazimah Hj Samin, Farhanah 
Embi, Lucy Cham Pou Lian, Rahimah Sahar dan Selladurai Palani (Eds).Teknologi maklumat dan komunikasi (ict): aliran pendidikan terkini. Bangi: Fakulti Pendidikan Universiti Kebangsaan Malaysia.

Motlik, S. 2008. Mobile Learning in Developing Nations. International Review of Research in Open and Distance Learning, 9 (2): 1-7

Motiwalla, L.F. (2007). Mobile learning: A framework and evaluation. Computers \& Education, 49: 581-596.

Naismith, L., Lonsdale, P., Vavoula,G \& Sharples, M. 2004. Teaching and learning with mobile technologies-case studies. Futurelab: www.futurelab.org.uk. [ 3 August 2009]

Pieri, M. \& Diamantini, D.(2009). From e-learning to mobile learning: new opportunities. Retrieved on 07 November 2018 from

https://www.researchgate.net/publication/255605676_From_Elearning_to_M obile_Learning_New_Opportunities

Rocca, S. (2009). Texting to teaching: reaching the millennial generation. The Agricultural Education Magazine, 82(1). Retrieved 19 January 2010 from Proquest Education Journal.

Roziah binti Abdullah. (2004). Pembangunan dan keberkesanan pakej multimedia kemahiran berfikir bagi mata pelajaran kimia. Ph.D Thesis. National University Malaysia.

Sharples, M. (2000). The design of personal mobile technologies for lifelong learning. Computers \& Education, Vol. 34, Issues 3-4, Retrieved on 07 November 2018 from: https://www.sciencedirect.com/science/article/pii/S0360131599000445

Tinio,V.L. (2003). ICT in education, UNDP-APDIP:

Tudor, I. (1996). Learner-centredness as Language Education Cambridge: Cambridge University Press 